DOI 10.31509/2658-607x-2020-3-2-1-16

УДК 631.41

ИЗМЕНЕНИЯ СОДЕРЖАНИЯ БИОДОСТУПНЫХ СОЕДИНЕНИЙ ТЯЖЕЛЫХ МЕТАЛЛОВ В ПОЧВАХ ГОРНЫХ ПЛАТО КРЫМА ПОСЛЕ ОБЛЕСЕНИЯ

\author{
(C) 2020 г. И.В. Костенко*, А.Р. Никифоров
}

Никитский ботанический сад - Наџиональный научный центр РАН

Россия, 298648, Ялта, спуск Никитский, 52

E-mail: ik_64@bk.ru

Поступила в редакцию: 17.11.2019 г.

Принята к печати 12.05.2020 г.

В результате облесения горных плато Крыма в середине прошлого столетия на их поверхности было создано около 3 тыс. га лесных насаждений. Исследования по изучению влияния этих насаждений на свойства горно-луговых почв (Phaeozems) показали, что под лесной растительностью произошло укрупнение структурных агрегатов, уменьшение гумусированности, увеличение кислотности по сравнению с почвами под луговой растительностью, что могло оказать влияние и на другие свойства почв, в том числе на подвижность ряда металлов. Цель настоящих исследований - провести сравнительный анализ содержания доступных для биоты соединений $\mathrm{Pb}, \mathrm{Mn}, \mathrm{Cu}$ и $\mathrm{Zn}$ (1 М ацетат аммония) в почве под горными лугами, естественным буковым лесом и под искусственными лесными насаждениями. Согласно полученным результатам в облесенных горно-луговых почвах произошло накопление доступных соединений $\mathrm{Pb}, \mathrm{Mn}$ и $\mathrm{Cu}$ относительно расположенных рядом участков горных лугов. Так, в слое почвы 0-10 см под насаждениями сосны крючковатой среднее содержание $\mathrm{Pb}$ по сравнению с почвой под луговой растительностью было больше в 1.6 раз, $\mathrm{Mn}-$ в 1.2 раза, $\mathrm{Cu}-$ в 1.2 раза. Под березой повислой $\mathrm{Pb}$ было больше в 2.5 раза, $\mathrm{Mn}$ - в 1.5 и $\mathrm{Cu}$ - в 1.2 раза. Под лиственницей сибирской $\mathrm{Pb}$ было больше в 2.2 раза, $\mathrm{Mn}$ - в 2.4 и $\mathrm{Cu}-$ в 1.5 раза. Под кленом ложноплатановым по сравнению с лугом содержалось в 1.9 раз больше $\mathrm{Pb}$, в $1.1-\mathrm{Mn}$ и в $1.3-\mathrm{Cu}$. Различия между облесенными и луговыми почвами по содержанию этих элементов в большинстве случаев были достоверными, кроме содержания $\mathrm{Zn}$, признаков накопления которого под искусственными насаждениями не выявлено. Содержание $\mathrm{Pb}, \mathrm{Mn}$ и $\mathrm{Cu}$ в буроземе лессивированном (Luvisols) под буком восточным соответствовало их концентрации под лиственницей, a Zn было значительно больше по сравнению с почвой под всеми породами. Основной причиной увеличения подвижности ряда элементов под насаждениями древесных пород является их переход из малоподвижных форм под воздействием повышенной кислотности облесенных почв. Древесный опад из-за низкого содержания микроэлементов в своем составе не может быть источником их накопления в верхнем слое почвы.

Ключевые слова: горно-луговые почвы, лесные насаждения, микроэлементы, кислотность, тяжелье металль

Подкисляющий эффект искусственных лесных насаждений на почвы бывших сельхозугодий и пастбищ отмечен многими исследованиями в различных природно-климатических зонах Мира (Alfredsson et al., 1998; Alriksson, Olsson, 1995; Andersen et al, 2002; Berthrong et al., 2009; Fullerr, Anderson, 1993; Jobbagy, Jackson, 2003; Holubik et al., 2014; Ritter et al., 2003; Wen-Jie et al., 2011). Результатом такого воздействия древесных растений на почву может быть увеличение концентрации доступных для биоты соединений некоторых микроэлементов, поскольку $\mathrm{pH}$ является ключевым фактором, влияющим на подвижность металлов в почве (Reddy et al., 1995; Sauve et al., 1998; Sherene, 2010). Интенсивное 
облесение ранее практически безлесых горных плато (яйл) Крыма началось в 1957 г. и до 70-х годов прошлого столетия на поверхности яйл Караби, Демерджи и АйПетринской было создано около 3 тыс. га искусственных лесных насаждений (Багрова, Гаркуша, 2009). Основные их массивы, состоящие из десятков отдельных куртин различного породного состава, сосредоточены на плато АйПетри. Среди древесных пород доминирует сосна обыкновенная, занимающая до $70 \%$ площадей, также встречаются массивы березы, осины, клена, фундука, лиственницы, груши, ели и других пород. Насаждения занимают относительно ровные участки, на которых сформировались горно-луговые почвы мощностью 50-150 см.

Ранее на плато Ай-Петри нами были проведены исследования по изучению влияния искусственных насаждений сосны, лиственницы и березы на основные свойства горно-луговых почв (Kostenko, 2018). Было выявлено, что под лесной растительностью произошло увеличение доли крупных агрегатов в составе почвенной структуры, уменьшение гумусированности, увеличение кислотности и содержания железа из органоминеральных соединений по сравнению с почвами под луговой растительностью. Наиболее сильные изменения структурного состояния почв наблюдались под насаждениями сосны, кислотности и содержания железа - под насаждениями лиственницы. О сильном подкисляющем воздействии на почву насаждений лиственницы свидетельствуют также данные М.Е. Ткаченко (1939) и Ф.И. Хакимов (Khakimov et al., 2005). Уменьшение гумусированности наблюдалось под всеми древесными породами.

Цель данной работы - сравнительный анализ содержания доступных для биоты соединений $\mathrm{Pb}, \mathrm{Mn}, \mathrm{Cu}$ и $\mathrm{Zn}$ в почве под искусственными лесными насаждениями и под залегающими рядом участками горных лугов.

\section{1. МАТЕРИАЛ И МЕТОДЫ 1.1 Объекты исследований}

Плато Ай-Петри относится к системе западных яйл Горного Крыма с абсолютными высотами 1100-1300 м над ур. моря. Климатические условия на его территории по данным метеостанции «АйПетри» $(1180$ м $)$ характеризуются среднегодовым количеством осадков 1052 мм, среднегодовой температурой $5.7^{\circ} \mathrm{C}$, средней температурой февраля $-3.8^{\circ} \mathrm{C}$, июля $-15.5^{\circ} \mathrm{C}$. Большая часть осадков (62\%) выпадает в холодное время года с ноября по март.

Ай-Петринский горный массив сложен плотными верхнеюрскими известняками, что является причиной активного развития карстовых процессов. По рельефу яйлы представляют собой холмистые нагорные плато с многочисленными карстовыми воронками, колодцами, шахтами и пещерами. Отрицательные формы рельефа заполнены выщелоченными продуктами выветривания известняков, на которых сформировались наиболее плодородные горно-луговые почвы, большая часть которых в настоящее время занята искусственными лесными насаждениями.

По морфологическому строению и свойствам эти почвы ближе всего к горнолуговым черноземовидным (Классификация ..., 1977), которые формируются под луговыми степями на сиаллитных продуктах выветривания известняков. Однако типичные черноземовидные почвы встречаются редко, поскольку основной массив полнопрофильных почв плато характеризуется полной выщелоченностью карбонатов, отсутствием в профиле обломков горной породы, кислой и сильнокислой реакцией. Наиболее гумусированным целинным разностям этих почв, сохранившимся локально в 
днищах карстовых воронок, присуща характерная для типа темно-серая с коричневым оттенком окраска гор. А, антропогенно нарушенным - сероватобурая (Костенко, 2014).

В современной классификации почв России горно-луговые почвы не представлены, а наиболее близким их аналогом является тип перегнойнотемногумусовых почв с профилем АН-C (Классификация ... 2004, с. 183), который не охватывает все почвенное разнообразие крымских яйл.

Пo WRB (IUSS Working Group, 2015) горно-луговые почвы плато относятся к Phaeozems - почвам с темноокрашенным гумусовым горизонтом, не содержащим в профиле вторичных карбонатов. Среди них встречаются остаточно карбонатные почвы (Calcaric), с признаками элювиирования глины (Luvic), подстилаемые плотными породами с глубины менее 100 см (Leptic) и с темноокрашенным гумусовым горизонтом (Chernic). Описанные в статье луговые и облесенные почвы относятся к Phaeozems (разр. 1353) и к Leptic Phaeozems (разр. 1280, 1281, $1332,1333,1351$ и 1379).

Горно-лесные почвы Крыма, залегающие от 300 м над ур. м. по южному макросклону Главной гряды и на плато, традиционно относят к бурым горнолесным или буроземам (Драган, 2004; Половицкий, Гусев, 1987), которым присущи слабая дифференциация профиля на генетические горизонты, кислая реакция, оглинивание всей толщи, отсутствие выноса ила либо слабый его вынос из верхних горизонтов (Классификация ..., 1977). По классификации 2004 г. буроземы отнесены к отделу структурно-метаморфических, для которых характерна кислая реакция и слабая дифференциация профиля по илу, а по WRB - к Cambisols. Однако с определением типовой принадлежности почвы букового леса возникли проблемы, поскольку она, при наличии основных признаков бурозема, отличается сильной текстурной дифференциацией профиля, вызванной, вероятней всего, активным лессиважем ила из верхних горизонтов. В связи с этим почву букового леса мы отнесли к бурозему лессивированному, который не представлен в классификациях почв России, но описан (Почвоведение ..., 1988) как текстурно-дифференцированная почва без морфологически выраженного горизонта Е. Наличие оглиненного горизонта argic является основанием для отнесения почвы букового леса (разр. 1272) к реферативной почвенной группе Luvisols по WRB.

В прошлом столетии территория АйПетринской яйлы до облесения и затем на свободных от насаждений участках интенсивно использовалась под пастбища, сенокосы и огороды для жителей Ялты. К моменту создания в 1974 г. Ялтинского горно-лесного природного заповедника наиболее плодородные почвы были сильно деградированы, поэтому даже многолетнее пребывание под залежью не привело к восстановлению их плодородия до исходного уровня. Высадка леса затормозила процесс гумусонакопления, поэтому содержание органического углерода в почвах под всеми искусственными насаждениями ниже, чем под травянистой растительностью на прилегающих к насаждениям участках горных лугов (Kostenko, 2018).

Почвенные исследования проводились в насаждениях сосны крючковатой (Pinus kochiana Klotzsch ex K. Koch), березы повислой (Betula pendula Roth), лиственницы сибирской (Larix sibirica Ledeb) и клена ложноплатанового (Acer pseudoplatanus L.), высаженных на плато Ай-Петри, судя по архивным данным Ялтинского горно-лесного природного заповедника, в период с 1958 до 1964 гг. К 
моменту исследований возраст насаждений колебался от 50 до 60 лет. Для оценки интенсивности накопления металлов под лесными насаждениями по сравнению с естественными лесами такие же исследования были проведены в естественном монодоминантном буковом лесу (Fagus orientalis Lipsky), в структуре которого преобладают насаждения VII-XII десятилетних классов возраста (Плугатарь, 2015).

Искусственные насаждения сосны, березы и клена представляли собой монодоминантные сообщества, подлесок которых состоял из единичных экземпляров шиповника (Rosa tschatyrdagi Chrshan.) и боярышника (Crataegus taurica Pojark.). В насаждениях лиственницы встречались также сосна, липа (Tilia cordata Mill.), ясень (Fraxinus excelsior L.) c рябиной (Sorbus aucuparia L.), шиповником и боярышником в подлеске. Высадку деревьев производили после вспашки почвы по загущенной схеме $2 \times$ 0.5-1.0 м, что привело к угнетению и выпадению большого количества деревьев к началу наших исследований.

Напочвенный покров под сосной, лиственницей и буком имел проективное покрытие 5-10\%, под березой и кленом $40-70 \%$. В травянистом покрове под насаждениями березы доминировали овсец Шелля (Helictotrichon schellianum (Hack.) Kitag.), ежа сборная (Dactylis glomerata L.), бородавник промежуточный (Lapsana intermedia M. Bieb.), тысячелистник щетинистый (Achillea setacea Waldst. \& Kit.), репешок аптечный (Agrimonia eupatoria L.), трясунка высокая (Briza australis Prokud.), буквица лекарственная (Betonica officinalis L.), пырей ползучий (Elytrigia repens (L.) Gould). Под изреженными насаждениями сосны произрастали райграс высокий (Arrhenatherum elatius (L.) P.Beauv. ex J.Presl \& C.Presl.), ежа сборная, крапива двудомная (Urtica dioica L.). Под лиственницей - коротконожка лесная (Brachypodium sylvaticum (Huds.) P. Beauv), ежа сборная, кипрей горный (Epilobium montanum L.), герань Роберта (Geranium robertianum L.), бородавник промежуточный, мятлик дубравный (Poa nemoralis L.), крапива двудомная. Под пологом букового леса выявлены единичные экземпляры ясменника пахучего (Galium odoratum (L.) Scop.).

В условиях повышенного увлажнения опад лиственных пород и лиственницы минерализуется достаточно быстро, поэтому мощность подстилки под ними не превышала 1-2 см и только под сосной достигала 4-6 см.

Примыкающие к лесным насаждениям участки плато по составу растительности относятся к луговой степи, типичной для Ай-Петринской яйлы. Доминирующими видами для луговых сообществ по нашим данным являются злаки: овсец Шелля (Helictotrichon schellianum (Hack.) Kitag.), трясунка высокая (Briza elatior Sibth. \& Sm.), пырей ползучий (Elytrigia repens (L.) Gould), мятлик луговой (Poa pratensis L.), ежа сборная (Dactylis glomerata L.), тимофеевка степная (Phleum phleoides (L.) H. Karst.), пырей щетинистый (Elytrigia strigosa (M. Bieb.) Nevski), а также тысячелистник щетинистый (Achillea setacea Waldst. \& Kit.), буквица лекарственная (Betonica officinalis L.), зверобой продырявленный (Hypericum perforatum L.), пахучка обыкновенная (Clinopodium vulgare L.), земляника зеленая (Fragaria viridis (Duchesne) Weston), подмаренник мягкий (Galium mollugo L.), медуница неясная (Pulmonaria obscura Dumort.) и некоторые другие виды.

\section{2 Методы исследований}

Почвенные разрезы были заложены под искусственными насаждениями лесных культур и бука, а также на прилегающих и к ним участках горных лугов до глубины 
залегания плотных пород, образцы из которых отбирались сплошной колонкой через 10 см. Также на каждом из вариантов было отобрано не менее 5 образцов из слоя 0-10 cM.

В почвенных образцах определяли гранулометрический состав методом пипетки после пирофосфатной диспергации почв, $\mathrm{pH}_{\mathrm{KCl}}$, гидролитическую кислотность (Нг) методом, содержание общего органического углерода (C общ) по Тюрину и содержание подвижных форм $\mathrm{Pb}, \mathrm{Mn}, \mathrm{Cu}$ и $\mathrm{Zn}$, переходящих в $1 \mathrm{M}$ аммонийно-ацетатную вытяжку с $\mathrm{pH} 4.8$ (Практикум по агрохимии, 2001).

Для изучения возможности поступления элементов в почву путем биологического переноса в середине августа были отобраны образцы свежих листьев березы, клена и бука, а сразу после листопада свежего опада листопадных пород, а также сосны из верхнего слоя подстилки. Содержание $\mathrm{Pb}, \mathrm{Mn}, \mathrm{Cu}$ и $\mathrm{Zn}$ в растительных образцах определяли после сухого озоления листьев и хвои. Определение всех элементов проводили на атомно-абсорбционном спектрометре Квант-2мт.

Измерения влажности в профиле почв под естественным буковым лесом, насаждениями лиственницы и под луговой растительность были проведены 10 октября 2014 г. с помощью электронного влагомера HH2 Delta-T.

Статистическая обработка результатов проводилась с использованием пакета программ STATISTICA 6 и онлайн-сервиса для расчета критерия Манна-Уитни.

\section{2. РЕЗУЛЬТАТЫ И ОБСУЖДЕНИЕ}

Результаты сравнительных исследований содержания и характера профильного распределения микроэлементов в буроземе букового леса и в горно-луговой почве плато Ай-Петри свидетельствуют о сильном влиянии типа растительности на эти показатели.

В профиле луговой почвы содержание большинства элементов ниже, а разброс величин меньше по сравнению с почвой букового леса (рис. 1). Это обусловлено большими различиями между почвами по основным характеристикам - содержанию ила, органического вещества и величинам pH (рис. 2), которые влияют на накопление валовых и подвижных форм микроэлементов (Тобратов и др., 2007). Различия между разрезами по содержанию всех элементов, кроме Zn, достоверны на уровне $\mathrm{p} \leq 0.01$.

По результатам множественного корреляционного анализа (табл. 1) содержание подвижного $\mathrm{Pb}$ в почве букового леса связано со всеми перечисленными почвенными факторами $\mathrm{Zn}$ - с содержанием ила и С общ, $\mathrm{Mn}$ - с содержанием $\mathrm{C}$ общ и $\mathrm{Cu}-\mathrm{c}$ содержанием ила.

На подвижность металлов могут оказывать влияние также и особенности гидрологического режима почв, формирующихся под различными типами растительности. Очевидно, что при сопоставимом количестве осадков влажность лесной почвы по сравнению с луговой будет выше за счет меньшей испаряемости затененной поверхности, защищенной также слоем лесной подстилки. По результатам измерений влажность почвы букового леса в слоях 10$15, \quad 30-35$ и $50-55$ см составила соответственно $25.4 \pm 1.8, \quad 35.7 \pm 2.2 \quad$ и $34.4 \pm 0.9 \%$, а луговой $-29.5 \pm 1.7,28.6 \pm 2.9$ и $27.4 \pm 2.5 \%$ от объема почвы при уровне значимости различий по критерию МаннаУитни $\leq 0.01$. Как видно, за счет осенних осадков, влажность почвы в слое 10-15 см была выше на открытых участках под луговой растительностью, а в более глубоких слоях - под лесной. 

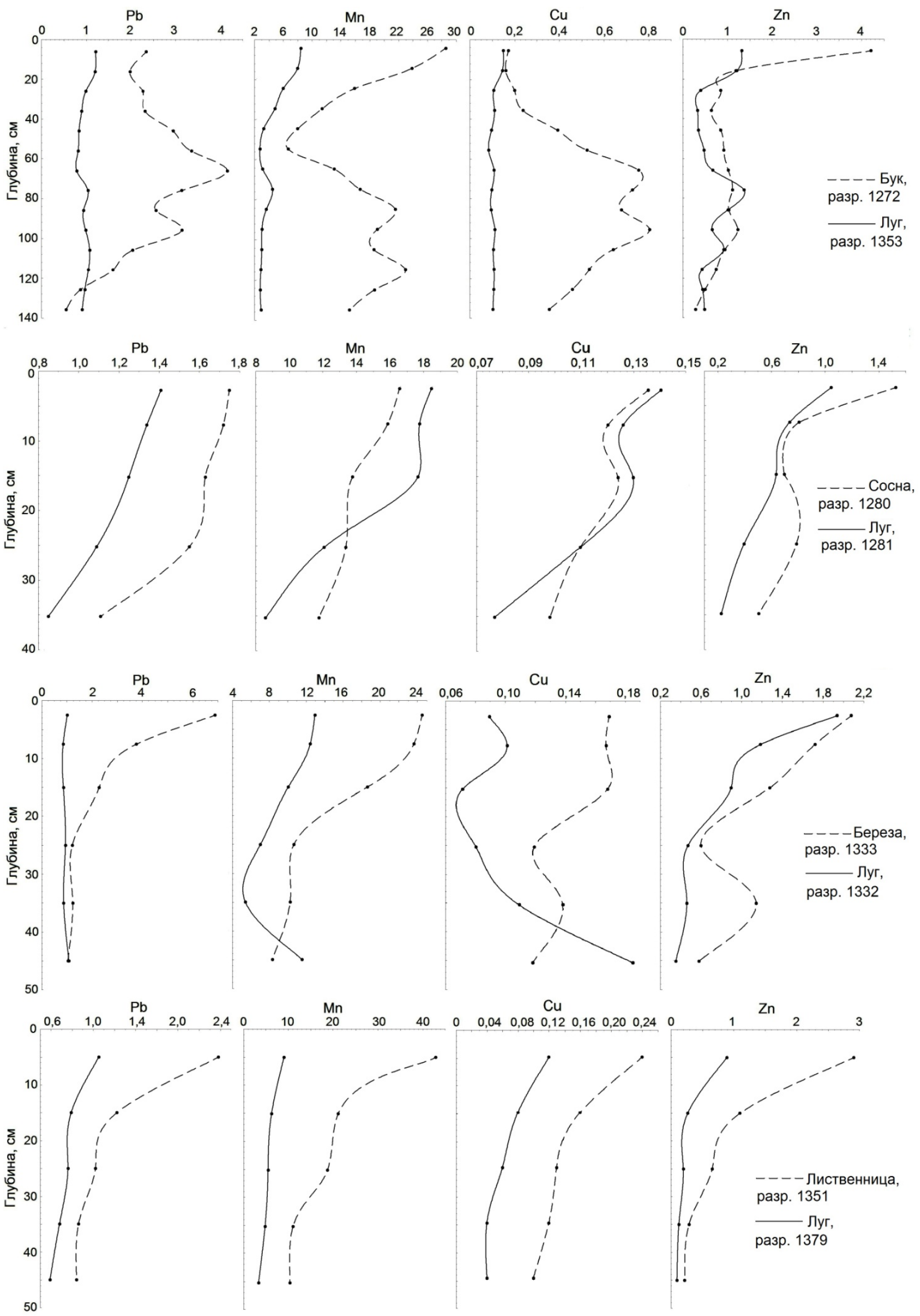

Рисунок 1. Профильное распределение доступных для биоты соединений $\mathrm{Pb}, \mathrm{Mn}, \mathrm{Cu}, \mathrm{Zn}$ в почве под естественным буковым лесом, искусственными насаждениями древесных пород и участками горных лугов 


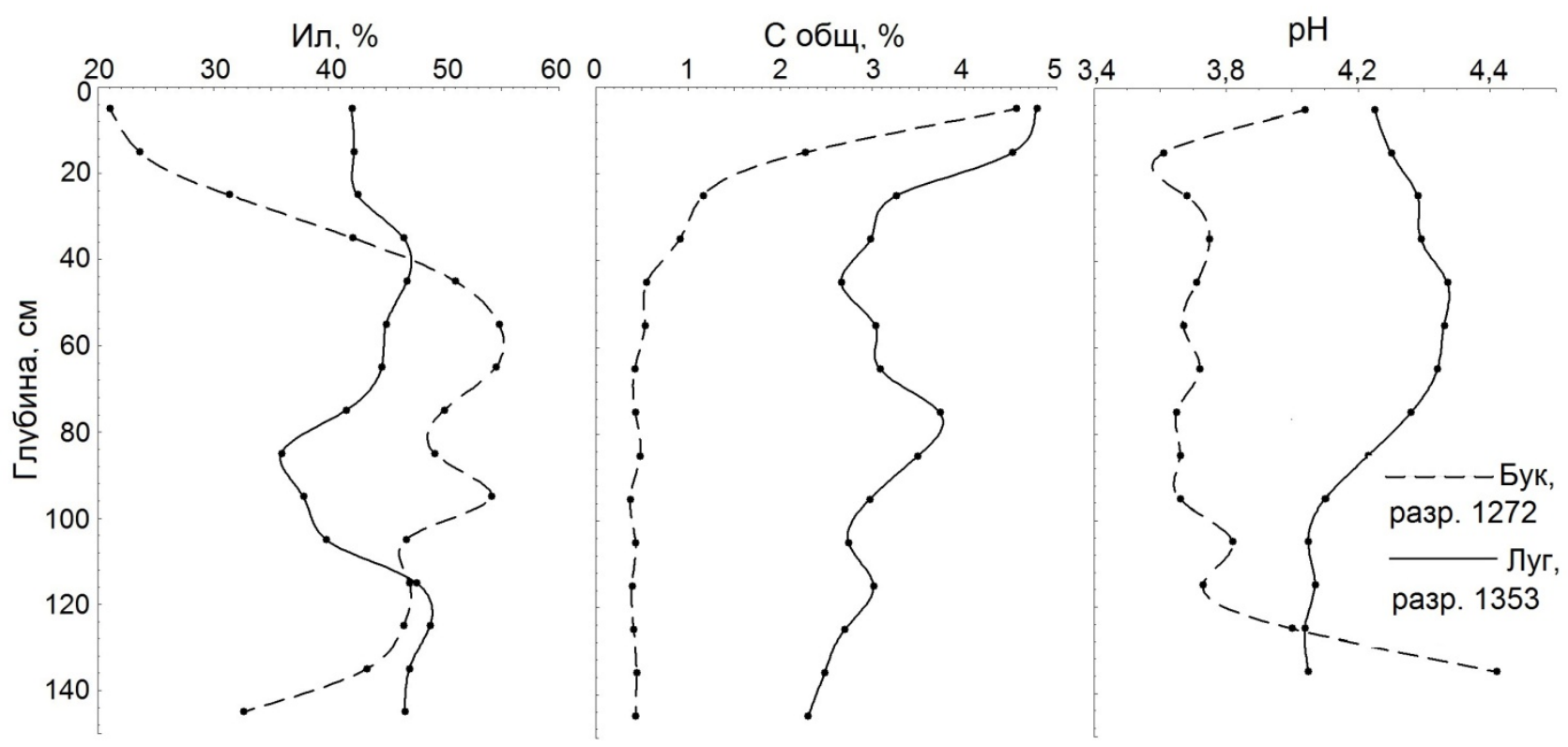

Рисунок 2. Профильное распределение ила, С общ и величин рН в почве под буковым лесом и под луговой растительностью

Таблица 1. Результаты множественного корреляционного анализа (n=16)

\begin{tabular}{|c|c|c|c|c|}
\hline Элемент & \multirow{2}{*}{\begin{tabular}{c} 
Коэффициент \\
множественной \\
\cline { 3 - 5 }
\end{tabular}} & \multicolumn{3}{|c|}{ Частные коэффициенты корреляции } \\
\cline { 3 - 5 } & Ил & С общ & Нг \\
\hline $\mathrm{Pb}$ & 0.94 & $0.72^{* *}$ & $0.58^{*}$ & $0.88^{* *}$ \\
\hline $\mathrm{Mn}$ & - & - & $0.67^{* *}$ & - \\
\hline $\mathrm{Cu}$ & - & $0.85^{* *}$ & - & - \\
\hline $\mathrm{Zn}$ & 0.95 & $0.69^{* *}$ & $0.92^{* *}$ & - \\
\hline
\end{tabular}

Примечание: * - коэффициенты корреляции значимые на уровне $\mathrm{p} \leq 0.05, * *-\mathrm{p} \leq 0.01$

Судя по профильному распределению в почве букового леса микроэлементов (рис. 1), наиболее сильному влиянию влажности, определяющей окислительновосстановительные условия почвы, подвержено распределение Mn. В верхней, более иссушаемой части профиля 0-60 см содержание Мn тесно связано с С общ $(\mathrm{r}=$ $0.94 ; \mathrm{n}=7)$, резко снижаясь с глубиной. В пределах более влажного слоя 60-80 cм содержание $\mathrm{Mn}$ резко возрастает и до 130 см колеблется в пределах близких значений, свидетельствуя о том, что легкоподвижные соединения $\mathrm{Mn}^{2+}$ образуются в периодически складывающихся восстановительных условиях (Азаренко, 2013; Орлов и др., 2005) средней и нижней частей профиля.

Воздействие леса на почвы под искусственными насаждениями происхо- дит всего в течение нескольких десятилетий с момента формирования достаточно сомкнутого полога, препятствующего росту трав. За этот период произошло изменение ряда химических свойств облесенных почв, что, однако, не отразилось на фундаментальных почвенных показателях, включая содержание и характер профильного распределения механических элементов и органического вещества. Поэтому, несмотря на изменение концентрации доступных для биоты соединений металлов под насаждениями лесных культур, характер их профильного распределения в большинстве случаев близок к распределению элементов под луговой растительностью (рис. 1). По всему профилю в почве под сосной содержалось больше $\mathrm{Pb}$ и $\mathrm{Zn}$ (рис. 1). 
Марганца и $\mathrm{Cu}$ в верхней части профиля содержалось больше под лугом, в нижней - под сосной, что, по всей видимости, обусловлено более высокой кислотностью луговой почвы в слое 0-40 см в месте закладки разреза 1281 (Нг = 8.9 смоль $(+) /$ кг) по сравнению с облесенной, где среднепрофильное значение составило Нг 7.8 смоль $(+) /$ кг. В связи с этим достоверной разница между разрезами на уровне $\mathrm{p} \leq 0.05$ была только для $\mathrm{Pb}$.

В почве под березой содержалось значительно больше $\mathrm{Pb}, \mathrm{Mn}$ и $\mathrm{Cu}$, особенно в верхней части профиля, при незначительной разнице по $\mathrm{Zn}$ по сравнению с луговой почвой. $\mathrm{У}$ дна разреза, при переходе к подстилающей породе эти различия нивелировались (рис. 1), а достоверными они были для $\mathrm{Pb}$ на уровне $\mathrm{p} \leq 0.01$ и $\mathrm{Cu}-\mathrm{p} \leq 0.05$.

Наибольшая разница по содержанию всех изученных элементов наблюдалась между луговой почвой и почвой под лиственницей, где она была достоверной на уровне $\mathrm{p} \leq 0.05$ для $\mathrm{Pb}, \mathrm{Cu}$ и $\mathrm{Zn}$ и на уровне $\mathrm{p} \leq 0.01$ - для $\mathrm{Mn}$. Как видно на рис. 1, с глубиной эти различия уменьшались, но сохранялись вплоть до подстилающих пород.

По сравнению с почвой под лугом, доступных соединений $\mathrm{Pb}$ достоверно больше накапливается в слое почвы 0-10 см под насаждениями всех пород, $\mathrm{Mn}-$ под лиственницей и березой, $\mathrm{Cu}$ - под всеми породами, кроме сосны, а по содержанию Zn разница между почвами под лесными насаждениями и луговой растительностью была недостоверной (табл. 2). Под естественным буковым лесом наблюдалось достоверно более высокое содержание доступных соединений всех металлов, включая Zn.

Таблица 2. Статистические показатели содержания элементов в слое почвы 0-10 см

\begin{tabular}{|c|c|c|c|c|c|}
\hline Растительность & Число & \multicolumn{4}{|c|}{ Содержание, мг/кг } \\
\cline { 3 - 6 } & повтор- & $\mathrm{Pb}$ & $\mathrm{Mn}$ & $\mathrm{Cu}$ & $\mathrm{Zn}$ \\
\cline { 3 - 6 } & ностей & & & & \\
\hline Сосна & 23 & $1.93 \pm 1.27^{* *}$ & $15.3 \pm 5.9$ & $0.29 \pm 0.22$ & $0.91 \pm 0.31$ \\
Луг & 24 & $1.20 \pm 0.59$ & $12.9 \pm 5.9$ & $0.25 \pm 0.16$ & $0.91 \pm 0.32$ \\
\hline Береза & 16 & $1.93 \pm 0.94^{* *}$ & $16.6 \pm 6.6^{* *}$ & $0.13 \pm 0.03^{*}$ & $1.21 \pm 0.92$ \\
Луг & 17 & $0.78 \pm 0.24$ & $11.0 \pm 3.9$ & $0.11 \pm 0.04$ & $1.06 \pm 0.47$ \\
\hline Лиственница & 10 & $2.70 \pm 1.23^{* *}$ & $24.1 \pm 8.4^{* *}$ & $0.21 \pm 0.03^{* *}$ & $1.48 \pm 0.53$ \\
Луг & 7 & $1.24 \pm 0.25$ & $10.1 \pm 2.8$ & $0.14 \pm 0.04$ & $1.33 \pm 0.29$ \\
\hline Клен & 5 & $1.37 \pm 0.46^{*}$ & $5.1 \pm 1.0$ & $0.10 \pm 0.02^{*}$ & $0.68 \pm 0.32$ \\
Луг & 5 & $0.74 \pm 0.11$ & $4.5 \pm 0.9$ & $0.08 \pm 0.02$ & $0.70 \pm 0.20$ \\
\hline Бук & 16 & $2.25 \pm 1.39^{* *}$ & $25.8 \pm 9.4^{* *}$ & $0.15 \pm 0.04^{* *}$ & $3.77 \pm 1.73^{* *}$ \\
Луг & 12 & $0.81 \pm 0.21$ & $11.0 \pm 3.9$ & $0.11 \pm 0.02$ & $1.20 \pm 0.45$ \\
\hline
\end{tabular}

Примечание: * - уровень значимости различий по критерию Манна-Уитни $\leq 0.05, * *-\leq 0.01$.

Основной причиной увеличения подвижности элементов под лесными насаждениями является увеличение кислотности почв, наблюдающееся под всеми лесными породами, кроме клена, где различия величин Нг по сравнению с луговой почвой недостоверны (табл. 3 ). 
Таблица 3. Кислотность, содержание или и органического углерода в слое почвы 0-10 см

\begin{tabular}{|c|c|c|c|c|}
\hline Растительность & $\begin{array}{c}\text { Число } \\
\text { повторностей }\end{array}$ & $\mathrm{pH}$ & Нг, смоль(+)/кг & С общ, \% \\
\hline Сосна & 23 & 4.18 & $9.3 \pm 2.9^{*}$ & $3.22 \pm 0.76$ \\
Луг & 24 & 4.51 & $7.2 \pm 2.01$ & $3.64 \pm 0.74$ \\
\hline Береза & 16 & 4.13 & $8.9 \pm 3.1^{* *}$ & $3.42 \pm 0.85^{* *}$ \\
Луг & 17 & 4.79 & $5.4 \pm 3.1$ & $4.45 \pm 0.88$ \\
\hline Лиственница & 10 & 3.76 & $16.2 \pm 1.4^{* *}$ & $3.61 \pm 0.36^{* *}$ \\
Луг & 7 & 4.62 & $9.0 \pm 0.9$ & $4.83 \pm 0.59$ \\
\hline Клен & 5 & 4.90 & $6.24 \pm 1.49$ & $4.08 \pm 0.26$ \\
Луг & 5 & 5.31 & $4.34 \pm 1.95$ & $4.98 \pm 1.46$ \\
\hline Бук & 16 & 3.73 & $13.0 \pm 4.3^{* *}$ & $4.16 \pm 0.74$ \\
Луг & 12 & 4.79 & $6.6 \pm 1.3$ & $4.0 \pm 0.64$ \\
\hline
\end{tabular}

Примечание: * - уровень значимости различий по критерию Манна-Уитни $\leq 0.05, * *-\leq 0.01$.

Увеличение подвижности металлов со снижением $\mathrm{pH}$, в том числе и под влиянием древесных насаждений, описано в ряде исследований. Результаты исследований М.К. Андерсен с соавторами (Andersen et al., 2004) свидетельствуют об увеличении кислотности под 34-летними насаждениями хвойных пород по сравнению с необлесенной почвой, с чем авторы связывают рост подвижности $\mathrm{Cd}$ и $\mathrm{Zn}$ в верхнем слое почвы под пихтой, a $\mathrm{Cu}$, $\mathrm{Ni}$ и $\mathrm{Pb}$ - под елью. Согласно результатам исследований Б.О. Берквист (Bergkvist,1987), изучавшего влияние ели, бука и необлесенных участков на кислотность почвенного раствора и подвижность металлов в лизиметрическом опыте, самые низкие значения $\mathrm{pH}$ и наиболее высокая подвижность металлов наблюдались под елью, наименьшие - под необлесенными участками. П. Ромкенс и В. Соломон (Römkens, Solomon 1998) отмечают, что, несмотря на более высокое валовое содержание $\mathrm{Cd}$ и $\mathrm{Zn}$ в пахотных почвах, обусловленное внесением навоза и минеральных удобрений, концентрация этих элементов в почвенном растворе была выше в более кислой почве под лесом.

Содержание органического вещества либо не влияло, либо оказывало очень слабое и разнонаправленное влияние на содержание подвижных форм некоторых металлов в облесенных почвах. Так, в почве под сосной слабая положительная связь С общ выявлена только с $\mathrm{Zn}(\mathrm{r}=0.48$; $\mathrm{n}=23$ ), под березой - отрицательная связь с
$\mathrm{Cu}(\mathrm{r}=-0.53)$ и $\mathrm{Zn}(\mathrm{r}=-0.63 ; \mathrm{n}=17)$. Влияние ила на содержание металлов во всех случаях было недостоверным.

Более тесные связи между свойствами почв и содержанием металлов в слое 0-10 см наблюдались в почве естественного букового леса. По данным множественного корреляционного анализа содержание $\mathrm{Pb}$ связано со всеми почвенными показателями с высокой степенью достоверности $\left(\mathrm{R}=0.92 ; \mathrm{r}_{\text {ил }}=0,58 ; \mathrm{r}_{\mathrm{C}}=\right.$ $\left.0.70 ; \mathrm{r}_{\mathrm{Hг}}=0.93 ; \mathrm{n}=16\right)$, марганца - с С общ и Нг $\left(\mathrm{R}=0.74 ; \mathrm{r}_{\mathrm{C}}=-0.52 ; \mathrm{r}_{\mathrm{Hг}}=0.67\right)$, так же как и цинка $\left(\mathrm{R}=0.82 ; \mathrm{r}_{\mathrm{C}}=-0.57 ; \mathrm{r}_{\mathrm{Hг}}=0.74\right)$. Менее всего от свойств почв зависело содержание $\mathrm{Cu}$, связанное только с содержанием $\mathrm{C}$ общ $(\mathrm{r}=-0.65)$. Положительная корреляция с илом и Нг вполне закономерна, поскольку минералы мелкодисперсной части почвы являются основным источником микроэлементов, а кислотность влияет на их подвижность. Разнонаправленное влияние С общ на содержание изученных металлов показывает, что эти связи могут иметь случайный характер, поскольку органическое вещество не является основным источником микроэлементов в лесных почвах, но при этом гуминовые и фульвокислоты могут связывать ионы металлов, поступающие в почву из различных источников, в нерастворимые органо-минеральные комплексы (Орлов и др., 2005).

При анализе всего массива данных по облесенным и луговым почвам Нг является 
единственным фактором, оказывающим достоверное влияние на содержание изученных элементов. Наиболее тесно Нг коррелирует с содержанием $\mathrm{Pb}$ и $\mathrm{Mn}$ (рис. 3), для которых характерна наибольшая разница между почвами под лесными насаждениями и под луговой расти- тельностью (табл. 2). Менее тесная корреляция наблюдается между Нг и $\mathrm{Cu}$, и самая слабая корреляция - между Нг и $\mathrm{Zn}$, поскольку количество цинка с увеличением кислотности почв под влиянием лесных насаждений практически не изменилось.
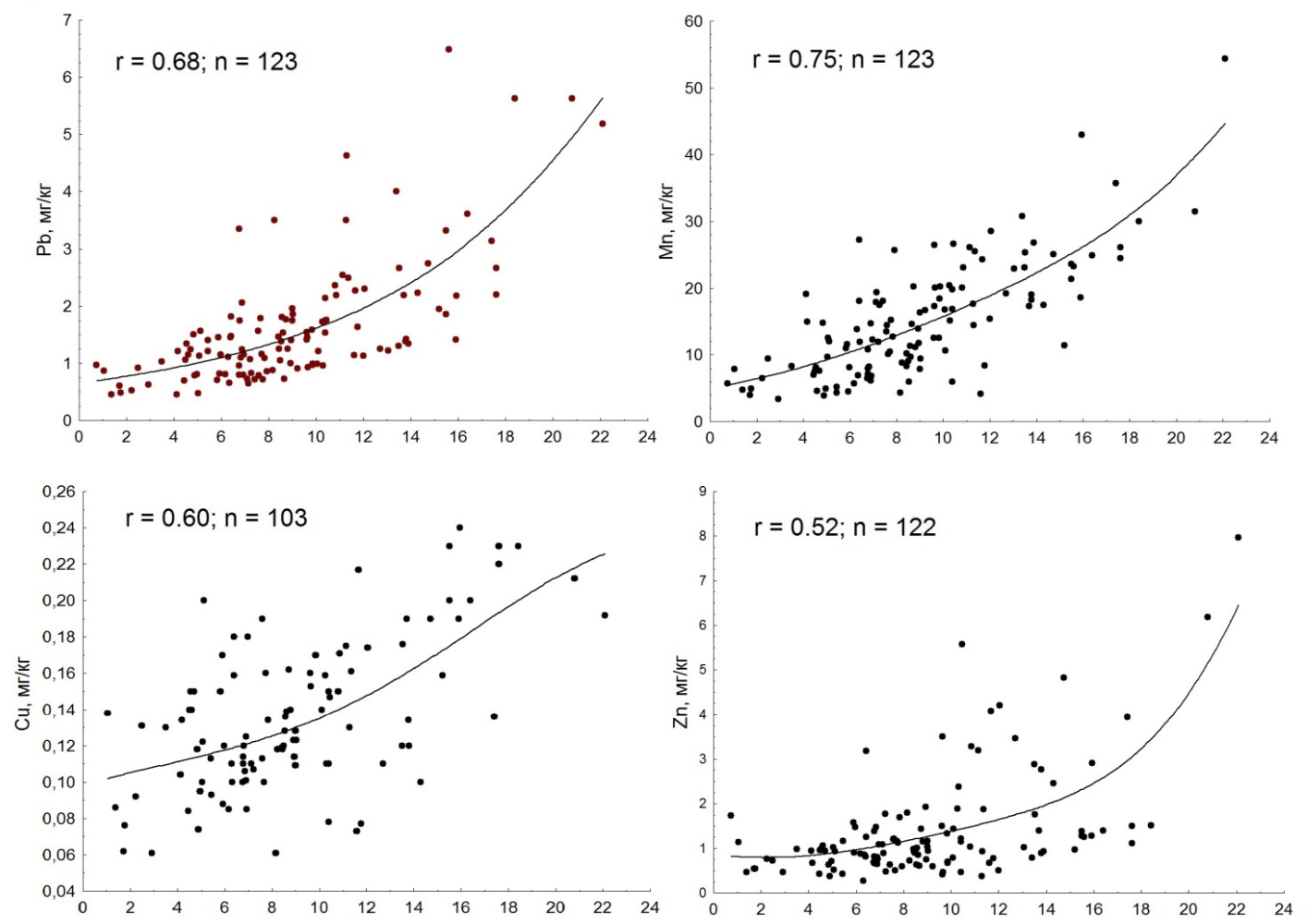

$\mathrm{Hг,} \mathrm{смоль(+)/кг}$

Рисунок 3. Влияние Нг на содержание элементов в слое почвы 0-10 см горно-луговых залежных и облесенных почв

Среди причин увеличения содержания ряда элементов в верхнем слое почвы под лесными насаждениями рассматривалась также возможность их привноса с древесным опадом. Как показали результаты анализа свежих листьев, в них содержалось определенное количество всех изучаемых элементов, кроме $\mathrm{Pb}$ (табл. 4), что за несколько десятилетий произрастания искусственных насаждений могло бы привести к аккумуляции $\mathrm{Mn}, \mathrm{Cu}$ и $\mathrm{Zn}$ в верхнем слое почвы. Однако в свежем опаде листопадных деревьев из всех элементов был обнаружен только Zn, причем в значительно меньших концентрациях, чем в живых листьях (табл. 4). Концентрации остальных элементов оказались ниже предела обнаружения. Из всех высаженных в период облесения плато пород только опад сосны мог быть источником поступления в почву микроэлементов, прежде всего цинка, однако это не подтверждается результатами определения его содержания в слое почве 0-10 см (табл. 2). В то же время высокое содержание цинка в слое 010 см под буком (табл. 2) и резкое снижение его концентрации с глубиной (рис. 1) свидетельствуют о возможности накопления цинка за счет растительного опада при условии длительного произрастания леса. 
Таблица 4. Содержание золы и элементов в опавших и в свежих листьях и хвое

\begin{tabular}{|c|c|c|c|c|c|}
\hline \multirow[t]{2}{*}{ Растение } & Зола, \% & $\mathrm{Pb}$ & $\mathrm{Mn}$ & $\mathrm{Cu}$ & $\mathrm{Zn}$ \\
\hline & \multicolumn{5}{|c|}{$\mathrm{M \Gamma} / \mathrm{\kappa} \Gamma$} \\
\hline \multicolumn{6}{|c|}{ Опад 2018 г. } \\
\hline Сосна & 2.62 & H.O. & 2.46 & 2.13 & 30.7 \\
\hline Лиственница & 5.25 & H.O. & H.о. & H.о. & 12.7 \\
\hline Береза & 4.82 & H.O. & H.O. & H.o. & 1.21 \\
\hline Клен & 9.27 & H.O. & H.O. & H.O. & 6.73 \\
\hline Бук & 5.63 & H.o. & H.O. & H.o. & 6.38 \\
\hline \multicolumn{6}{|c|}{ Листья, отобранные 15.08.2019 г. } \\
\hline Береза & 4.42 & H.O. & 16.1 & 4.21 & 92.6 \\
\hline Клен & 9.03 & H.O. & 7.67 & 6.14 & 30.7 \\
\hline Бук & 5.45 & H.O. & 24.8 & 5.66 & 26.3 \\
\hline
\end{tabular}

н.о. - не обнаружено.

\section{3. ВЫВОДЫ}

Произрастание искусственных лесных насаждений на горно-луговых почвах плато Ай-Петри в течение 60-летнего периода обусловило повышение их кислотности относительно расположенных рядом участков горных лугов и накопление некоторых микроэлементов.

Наибольшая разница между содержанием доступных для биоты соединений элементов в слое почвы 0-10 см под насаждениями лесных пород и под луговой растительностью выявлена для $\mathrm{Pb}$ и $\mathrm{Mn}$ (кроме клена) и гораздо меньшая для $\mathrm{Cu}$ и $\mathrm{Zn}$.

По сравнению с почвой естественного букового леса только под лиственницей в слое 0-10 см наблюдалось более высокое либо близкое содержание всех элементов,

\section{СПИСОК ЛИТЕРАТУРЫ}

Азаренко Ю.А. Закономерности содержания, распределения, взаимосвязей микроэлементов в системе почварастение в условиях юза Западной Сибири. Омск: Вариант-Омск, 2013. 232 c.

Багрова Л.А., Гаркуша Л.Я. Искусственные лесонасаждения в Крыму // Экосистемы, их оптимизация и охрана. 2009. Вып. 20. С. 134-145.

Драган Н.А. Почвенные ресурсы Крыма: Научная монография. 2-е изд., доп. Симферополь: ДОЛЯ, 2004. 208 с.

Классификация и диагностика почв России. Смоленск: Ойкумена, 2004. 342 с. кроме Zn. Повышенное содержание $\mathrm{Cu}$ под сосной обусловлено ее повышенным содержанием в почве прилегающих к сосне участков луга.

Основной причиной увеличения подвижности ряда элементов под насаждениями древесных пород является их переход из малоподвижных форм под воздействием повышенной кислотности облесенных почв.

Отсутствие, либо крайне низкое содержание элементов в опаде исключает возможность их аккумуляции в верхнем слое почвы под относительно молодыми насаждениями в результате минерализации хвои и листьев, однако длительное произрастание букового леса приводит к накоплению доступного цинка.

Классификачия и диагностика почв СССР. М.: Колос, 1977. 223 c.

Костенко И.В. Атлас почв Горного Крыма. Київ: Аграрна наука, 2014. 184 с.

Орлов Д.С., Садовникова Л.К., Суханова Н.И. Химия почв: Учебник. М.: Высш. шк., 2005. $558 \mathrm{c}$.

Плугатарь Ю.В. Леса Крыма: Монография. Симферополь: ИТ «АРИАЛ», 2015. $385 \mathrm{c}$.

Половицкий И.Я., Гусев П.Г. Почвы Крыма и повышение их плодородия. Симферополь: Таврия, 1987. 152 с.

Почвоведение: Учеб. для ун-тов. В 2 ч. / Под ред. В.А. Ковды, Б.Г. Розанова. Ч. 2. Типы почв, их география и 
использование / Богатырев Л.Г., Васильевская В.Д., Владычевский А.С. и др. М.: Высш. шк., 1988. 368 с.

Практикум по агрохимии: Учеб. пособие. / Под ред. В.Г. Минеева. М.: Изд-во МГУ, 2001. $689 \mathrm{c.}$

Tкаченко M.E. Влияние отдельных древесных пород на почву // Почвоведение. 1939. №10. С. 3-16.

Тобратов С.А., Попов В.И., Попова А.В. Факторы и закономерности миграции тяжелых металлов в лесных геосистемах Рязанского региона // Вопросы региональной географии и геоэкологии: Материалы региональной научно-практической конференции: Межвузовский сборник научных трудов. / Отв. ред. В.А. Кривцов; РГУ им. С.А. Есенина. 2007. Выпуск 7. Рязань: Рязанский государственный университет имени С.А. Есенина, 2007. C. 84-114.

Alfredsson H., Condron L.M., Clarholm M., Davis M.R. Changes in soil acidity and organic matter following the establishment of conifers on former grassland in $\mathrm{New}$ Zealand // Forest Ecology \& Management. 1998. Vol. 112. P. 245-252.

Alriksson A., Olsson M.T. Soil changes in different age classes of Norway spruse (Picea abies (L.) Karst.) on afforested farmland // Plant and Soil. 1995. Vol. 168169. P. 103-110.

Andersen M.K., Raulund-Rasmussen K., Hansen H.C.B., Strobel B.W. Distribution and fractionation of heavy metals in pairs of arable and afforested soils in Denmark // European Journal of Soil Science. 2002. Vol. 53. P. 491-502.

Andersen M.K., Raulund-Rasmussen K., Strobel B.W., Hansen H.C.B. The Effects of Tree Species and Site on the Solubility of $\mathrm{Cd}, \mathrm{Cu}, \mathrm{Ni}, \mathrm{Pb}$ and $\mathrm{Zn}$ in Soils // Water, Air, and Soil Pollution. 2004. Vol. 154. Issue 1-4. P. 357-370.

Bergkvist B.O. Leaching of metals from forest soils as influenced by tree species and management // Forest Ecology and Management. Vol. 22(1-2). 1987. P. 2956.

Berthrong S.T., Jobbagy E.G., Jackson R.B. A global meta-analysis of soil exchangeable cations, $\mathrm{pH}$, carbon, and nitrogen with afforestation // Ecological Applications. 2009. Vol. 19. No 8. P. 2228-2241.

Fullerr L.G., Anderson D.W. Changes in soil properties following forest invasion of Black soils of the Aspen Parkland // Can. J. Soil. Sci. 1993. Vol. 73. No 4. P. 613-627.

Holubik O., Podrazsky V., Vopravil J., Khel $T$., Remeš $J$. Effect of agricultural lands afforestation and tree species composition on the soil reaction, total organic carbon and nitrogen content in the uppermost mineral soil profile // Soil and Water Res. 2014. No 9. P. 192-200.

IUSS Working Group WRB. World Reference Base for Soil Resources 2014, update 2015. International soil classification system for naming soils and creating legends for soil maps. World Soil Resources Reports № 106. FAO, Rome. $192 \mathrm{p}$.

Jobbagy E.G., Jackson R.B. Patterns and mechanisms of soil acidification in the conversion of grasslands to forests // Biogeochemistry. 2003. Vol. 64. P. 205229.

Khakimov F.I., Volokitin M.P., Syroizhko N.P. Changes in gray forest soils under larch stands // Eurasian Soil Science. 2005. Vol. 38. No 6. P. 576-585.

Kostenko I.V. The Impact of artificial forest plantations on mountain-meadow soils of Crimea // Eurasian Soil Science. 2018. Vol. 51. No. 5. P. 485-494.

Reddy K.J., Wang L., Gloss S.P. Solubility and mobility of copper, zinc and lead in acidic environments // Plant and Soil. 1995. Vol. 171. P. 53-58.

Ritter E., Vesterdal L., Gundersen P. Changes in soil properties after afforestation of former intensively managed soils with oak and Norway spruce // Plant and Soil. 2003 Vol. 249. P. 319-330.

Römkens P.F.A.M., Solomon W. Cd, $\mathrm{Cu}$ and $\mathrm{Zn}$ solubility in arable and forest soils: consequences of land use change for metal mobility and risk assessment // Soil Science. 1998. Vol. 163. No 11. P. 859871.

Sauve S., Murray McBride M., Hendershot W. Soil Solution Speciation of Lead (II): Effects of Organic Matter and $\mathrm{pH} / /$ Soil 
Sci. Soc. Am. J. 1998. Vol. 62. P. 618-621.

Sherene T. Mobility and transport of heavy metals in polluted soil environment // Biological Forum - An International Journal. 2010. Vol. 2. No 2. P. 112-121.

Wen-Jie W., Ling Q., Yuan-Gang Z., DongXue S., Jing A., Hong-Yan W., Guan-Yu Z., Wei $S$., Xi-Quan C. Changes in soil organic carbon, nitrogen, $\mathrm{pH}$ and bulk density with the development of larch (Larix gmelinii) plantations in China // Global Change Biology. 2011. Vol. 17. No 8. P. 26572676.

\section{REFERENCES}

Alfredsson H., Condron L.M., Clarholm M., Davis M.R., Changes in soil acidity and organic matter following the establishment of conifers on former grassland in New Zealand, Forest Ecology \& Management, 1998, Vol. 112, pp. 245-252.

Alriksson A., Olsson M.T., Soil changes in different age classes of Norway spruse (Picea abies (L.) Karst.) on afforested farmland, Plant and Soil, 1995, Vol. 168169, pp. 103-110.

Andersen M.K., Raulund-Rasmussen K., Hansen H.C.B., Strobel B.W. Distribution and fractionation of heavy metals in pairs of arable and afforested soils in Denmark, European Journal of Soil Science, 2002, Vol. 53, pp. 491-502.

Andersen M.K., Raulund-Rasmussen K., Strobel B.W., Hansen H.C.B., The Effects of Tree Species and Site on the Solubility of $\mathrm{Cd}, \mathrm{Cu}, \mathrm{Ni}, \mathrm{Pb}$ and $\mathrm{Zn}$ in Soils, Water, Air, and Soil Pollution, 2004, Vol. 154 (14), pp. 357-370.

Azarenko Ju.A., Zakonomernosti soderzhanija, raspredelenija, vzaimosvjazej mikrojelementov v sisteme pochva-rastenie v uslovijah juza Zapadnoj Sibir (Regularities of the content, distribution, interconnections of microelements in the soil-plant system in the conditions of the southwestern Siberia), Omsk: VariantOmsk, 2013. 232 p.

Bagrova L.A., Garkusha L.Ja., Iskusstvennye lesonasazhdenija v Krymu (Artificial Afforestation in Crimea), Jekosistemy, ih optimizacija i ohrana, 2009, Vol. 20, pp. 134-145.
Bergkvist B.O., Leaching of metals from forest soils as influenced by tree species and management, Forest Ecology and Management, 1987, Vol. 22 (1-2), pp. 2956.

Berthrong S.T., Jobbagy E.G., Jackson R.B., A global meta-analysis of soil exchangeable cations, $\mathrm{pH}$, carbon, and nitrogen with afforestation, Ecological Applications, 2009, Vol. 19, No. 8, pp. 2228-2241.

Dragan N.A., Pochvennye resursy Kryma. Nauchnaja monografija (Soil resources of Crimea. Scientific monograph), 2-e izd., dop. Simferopol': DOLJa, 2004. 208 p.

Fullerr L.G., Anderson D.W., Changes in soil properties following forest invasion of Black soils of the Aspen Parkland, Can. J. Soil. Sci., April 1993, Vol. 73, No. 4, pp. 613-627.

Holubik O., Podrazsky V., Vopravil J., Khel T., Remes J., Effect of agricultural lands afforestation and tree species composition on the soil reaction, total organic carbon and nitrogen content in the uppermost mineral soil profile, Soil and Water Res., September 2014, No. 9. pp. 192-200.

IUSS Working Group WRB. World Reference Base for Soil Resources 2014, update 2015. International soil classification system for naming soils and creating legends for soil maps. World Soil Resources Reports No 106, FAO, Rome. $192 \mathrm{p}$.

Jobbagy E.G., Jackson R.B. Patterns and mechanisms of soil acidification in the conversion of grasslands to forests, Biogeochemistry, 2003, Vol. 64, pp. 205229.

Khakimov F.I., Volokitin M.P., Syroizhko N.P., Changes in gray forest soils under larch stands, Eurasian Soil Science, 2005, Vol. 38. No. 6, pp. 576-585.

Klassifikacija i diagnostika pochv Rossii (Classification and diagnostics of Russian soils), Smolensk: Ojkumena, 2004. 342 p.

Klassifikacija i diagnostika pochv SSSR (Classification and diagnostics of soils of the USSR), M.: Kolos, 1977. 223 p.

Kostenko I.V., Atlas pochv Gornogo Kryma (Soil atlas of the Mountain Crimea), Kiïv: Agrarna nauka, 2014. 184 p. 
Kostenko I.V., The Impact of Artificial Forest Plantations on Mountain-Meadow Soils of Crimea, Eurasian Soil Science, 2018, Vol. 51, No. 5, pp. 485-494.

Orlov D.S., Sadovnikova L.K., Suhanova N.I., Himija pochv (Soil chemistry), Moscow: Vyssh. shk., 2005. 558 p.

Plugatar' Ju.V. Lesa (Crimean forests), Simferopol': IT «ARIAL», 2015, 385 p.

Pochvovedenie (Soil science), Ucheb. dlja untov. V.A. Kovda, B.G. Rozanov (eds.). Vol. 2., Moscow: Vyssh. shk., 1988. 368 p.

Polovickij I.Ja., Gusev P.G., Pochvy Kryma $i$ povyshenie ih plodorodija (Crimean soils and increasing their fertility), Simferopol: Tavrija, 1987, $152 \mathrm{p}$.

Praktikum po agrohimii (Workshop on Agrochemistry), V.G. Mineev (ed.), Moscow: Izd-vo MGU, 2001, 689 p.

Reddy K.J., Wang L., Gloss S.P., Solubility and mobility of copper, zinc and lead in acidic environments, Plant and Soil, 1995, Vol. 171, pp. 53-58.

Ritter E., Vesterdal L., Gundersen P., Changes in soil properties after afforestation of former intensively managed soils with oak and Norway spruce, Plant and Soil, 2003, Vol. 249, pp. 319-330.

Römkens P.F.A.M., Solomon W., Cd, $\mathrm{Cu}$ and $\mathrm{Zn}$ solubility in arable and forest soils: consequences of land use change for metal mobility and risk assessment, Soil Science, 1998. Vol. 163. No. 11, pp. 859-871.
Sauve S., Murray McBride M., Hendershot W., Soil Solution Speciation of Lead (II): Effects of Organic Matter and pH, Soil Sci. Soc. Am. J., 1998, Vol. 62, pp. 618-621.

Sherene T. Mobility and transport of heavy metals in polluted soil environment, Biological Forum - An International Journal, 2010, Vol. 2. No. 2, pp 112-121.

Tkachenko M.E. Vlijanie otdel'nyh drevesnyh porod na pochvu (The Influence of Individual Tree Species on Soil), Pochvovedenie, 1939, No. 10, pp. 3-16.

Tobratov S.A., Popov V.I., Popova A.V., Faktory i zakonomernosti migracii tjazhelyh metallov v lesnyh geosistemah Rjazanskogo regiona (Factors and patterns of heavy metal migration in forest geosystems of the Ryazan region), Voprosy regional'noj geografii $i$ geojekologii: Materialy regional'noj nauchnoprakticheskoj konferencii: Mezhvuzovskij sbornik nauchnyh trudov, Vypusk 7, Rjazan': Rjazanskij gosudarstvennyj universitet imeni S.A. Esenina, 2007. pp. 84-114.

Wen-Jie W., Ling Q., Yuan-Gang Z., DongXue S.,Jing A., Hong-Yan W., Guan-Yu Z., Wei S., Xi-Quan C., Changes in soil organic carbon, nitrogen, $\mathrm{pH}$ and bulk density with the development of larch (Larix gmelinii) plantations in China, Global Change Biology, 2011, Vol. 17, No. 8, pp 2657-2676. 


\title{
CHANGES IN THE CONTENT OF BIOAVAILABLE HEAVY METAL COMPOUNDS IN THE SOILS OF CRIMEAN MOUNTAIN PLATEAUS AFTER AFFORESTATION
}

\author{
I.V. Kostenko*, A.R. Nikiforov \\ Nikitskii Botanical Garden - National Science Center, Russian Academy of Sciences, \\ Russia, 298648, Yalta, Nikitskiy Spusk,52 \\ *E-mail: ik_64@bk.ru \\ Received 17.11.2019 \\ Accepted 12.05.2020
}

As a result of afforestation of the Crimean mountain plateaus in the middle of the last century, about 3 thousand hectares of forest plantations were created on their surface. Studies on the influence of these plantations on the properties of mountain-meadow soils (Phaeozems) have shown that under the forest vegetation there were an enlargement of structural aggregates, a decrease in humus content, and an increase in acidity compared to soils under meadow vegetation, which could also affect other soil properties, including the mobility of some metals. The purpose of this research is a comparative analysis of the content of mobile forms of $\mathrm{Pb}, \mathrm{Mn}, \mathrm{Cu}$ and $\mathrm{Zn}(1 \mathrm{M}$ ammonium acetate) in the soils under mountain meadows, natural beech forest and artificial forest plantations. According to the results obtained, mobile $\mathrm{Pb}, \mathrm{Mn}$, and $\mathrm{Cu}$ were accumulated in forested mountainmeadow soils relative to adjacent areas of mountain meadows. So, in the soil layer of $0-10 \mathrm{~cm}$ under stands of pine (Pinus kochiana Klotzsch ex K. Koch), the average Pb content in comparison with soil under meadow vegetation was more than 1.6 times, $\mathrm{Mn}-1.2$ times, $\mathrm{Cu}-$ in 1.2 times. Under the birch (Betula pendula Roth), $\mathrm{Pb}$ was 2.5 times more, Mn was 1.5 times more, and $\mathrm{Cu}$ was 1.2 times more. Under larch (Larix sibirica Ledeb), $\mathrm{Pb}$ was 2.2 times higher, Mn was 2.4 times higher, and $\mathrm{Cu}$ was 1.5 times higher. In comparison with the meadow, the soil under maple (Acer pseudoplatanus L.) contained 1.9 times more $\mathrm{Pb}, 1.1-\mathrm{Mn}$, and 1.3 - $\mathrm{Cu}$. Differences between forested and meadow soils in the content of these elements in most cases were reliable, except for the content of $\mathrm{Zn}$, signs of accumulation of which under artificial plantings were not revealed. The content of $\mathrm{Pb}, \mathrm{Mn}$ and $\mathrm{Cu}$ in the brown forest soil (Luvisols) under the beech (Fagus orientalis Lipsky) corresponded to their concentration under the larch, and $\mathrm{Zn}$ was significantly higher compared to the soil under all tree species. The main reason for increasing the mobility of a number of elements under tree stands is their transformation from low mobility forms under the influence of increased acidity of forested soils. Leaf litter due to the low content or complete absence of trace elements in its composition cannot be a source of their accumulation in the upper layer of the soil.

Key words: mountain-meadow soils, forest plantations, microelements, acidity, heavy metals 
Рецензент: к.б.н., с.н.с. Тебенькова Д.Н. 